\title{
日本コンピュータ外科学会選奨結果報告
}

本学会では 2001 年度より選奨制度を開始し、コンピュータ外科学の領域に貢献する学術および関 連事業における業績を選奨してまいりました。

2013 年度論文賞と 2012 年度 Young Investigator Award（日立メディコ賞）の選奨結果は以下のとお りです。2013 年度日本コンピュータ外科学会大会（東京大学）において授賞式を行ったことととも にご報告いたします。会員の皆様におかれましては、本選奨制度の趣旨をご理解いただくとともに、 今後とも本学会への積極的なご参加とご協力をお願い申し上げます。

選奨委員会副委員長 篠原一彦 (東京工科大学)

\section{2013 年度論文賞}

本賞は本誌に発表された投稿論文から，コンピュータ外科領域に大きく貢献する特に優秀な論文の著者に贈呈 するもので, 医学賞, 工学賞, 優秀症例賞の 3 種類に分かれます，本年度は以下の 4 編に授賞を行ない副賞とし て記念の楯を贈呈しました.

\section{論文賞 (医学賞)}

○13（2）術室内映像を用いた潜在的リスク源候補半自動抽出システムの開発 鈴木孝司，櫻井康雄，吉光喜太郎，南部恭二郎，村垣善浩，伊関洋．

○14（2）手術ナビゲーションシステムにおける「近接覚」提示誘導法の提案と評価 中村亮一, 本多有芽, 佐藤生馬.

\section{論文賞 (工学賞)}

○13（2）高温加熱処理によるマイクロ光造形樹脂の細胞毒性低隇手法 井上佳則，生田幸士。

○14（1）低侵襲体内深部手術用非金属性柔剛可変ガイド管の開発および in vivo による臨床有用性評価 左思洋, 正宗賢, 桑名健太, 土肥健純.

\section{2012 年度 Young Investigator Award（日立メディコ賞）}

本賞は日立メディコ（株）のご支援のもとに 2003 年度よりスタートした賞で，コンピュータ外科領域におい て今後の活躍が期待できる若手研究者に対し授賞するものです．Gold 賞に 100,000 円， Silver 賞には 50,000 円 の副賞を授与しております。 なお受賞者には翌年度の大会での報告と本誌への論文投稿をお願いしております. 2012 年度は以下の 2 名の方々が受賞しました。

Gold 賞：林雄一郎先生（名古屋大学 情報連携統括本部情報戦略室）

Silver 賞: 荒田純平先生（九州大学先端医療イノベーションセンター） 


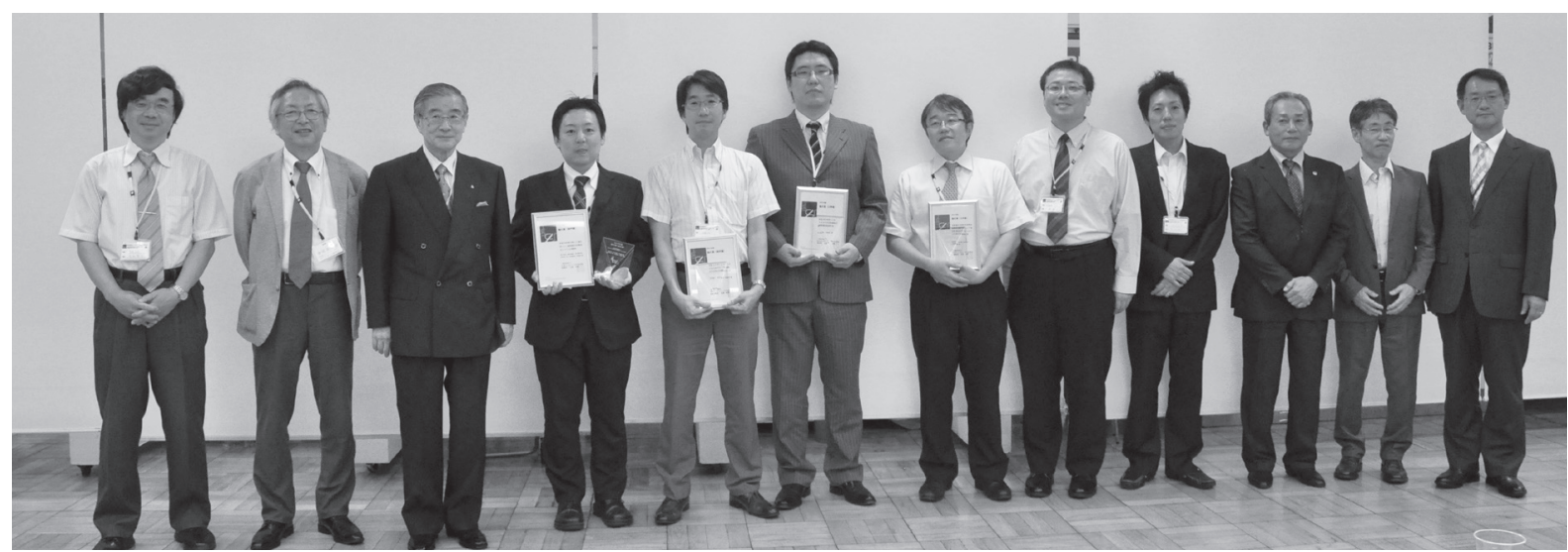

2013年度論文賞授賞式を終えて : 左から, 工学賞 ·生田幸士氏, 渡辺英寿選奨委員長, 北島政樹理事長, 医学賞 ·鈴木孝司氏, 医学賞・ 中村亮一氏, 工学賞・井上佳則氏, 工学賞・正宗 賢氏 (左 思洋氏代理), 日立メディコ賞・林雄一郎氏, 日立メディコ賞・荒田純平氏, (株)日立メディコ佐々木茂延氏, (株)日立メディコ前田常雄氏, 光石 衛第22回大会長

2012年度Young Investigator Award（日立メディコ 賞)授賞式を終えて : 左から, 渡辺英寿選奨委員長, 株日 立メディコ佐々木茂延氏, Silver賞·荒田純平氏, Gold賞・ 林雄一郎氏, 北島政樹理事長, 光石 衛第22回大会長

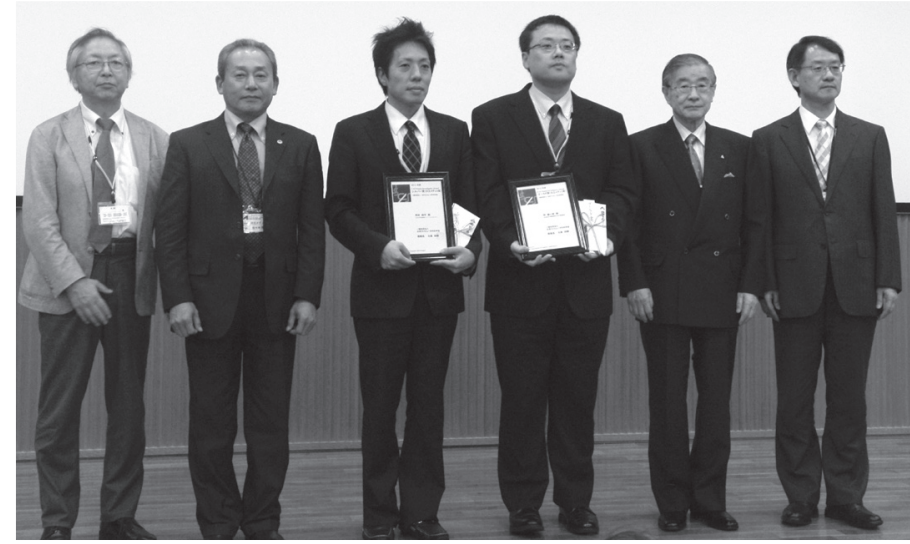

\section{日本コンピュータ外科学会 2013 年度選奨委員会}

委 員 長 渡辺英寿＼cjkstart自治医科大学脳神経外科

副委員長 篠原一彦東京工科大学医療保健学部

委 員 浅原利正 広島大学

伊関 洋 東京女子医科大学大学院 先端工学外科学分野

大西五三男 国際医療福祉大学

加藤天美 大阪大学大学院 医学系研究科

小杉幸夫東京工業大学総合理工学研究科

小林寿光 国立がんセンター

佐久間一郎 東京大学大学院工学系研究科

佐藤嘉伸大阪大学大学院医学系研究科

菅野伸彦大阪大学大学院医学系研究科

杉町圭蔵おんが病院

土肥健純＼cjkstart東京電機大学工学部

友田幸一関西医科大学耳鼻咽喉科

橋爪 誠九州大学大学院医学研究院

橋本大定東和病院

幹事 苗村 潔東京工科大学医療保健学部 